\title{
BERAT BADAN LAHIR RENDAH BERPENGARUH TERHADAP KEJADIAN ANEMIA DEFISIENSI BESI DI WILAYAH PUSKESMAS JATILAWANG KABUPATEN BANYUMAS
}

\author{
Sawitri Dewi ${ }^{1}$ \\ E-Mail : sawitridewi79@gmail.com \\ Prodi Kebidanan DIII Fakultas Ilmu Kesehatan Universitas Muhammadiyah Purwokerto \\ Jl. Soepardjo Roestam Km. 7 Sokaraja, Kabupaten Banyumas, Jawa Tengah
}

\begin{abstract}
Abstrak
Anemia defisiensi besi (ADB) merupakan penyakit nutrisi yang banyak terjadi di seluruh dunia, hal ini berpengaruh kepada perempuan pada masa reproduksi dan anak- anak usia kurang dari 5 tahun dan menyebabkan masalah kesehatan yang serius seperti penurunan kecerdasan dan perkembangan motorik serta perilaku. Beberapa hasil penelitian menyatakan bahwa ADB berkaitan dengan prematur atau bayi berat badan lahir rendah (BBLR), jenis kelamin, dan durasi menyusui. Penelitian ini bertujuan untuk mengetahui faktor risiko yang berkaitan dengan kejadian anemia defisiensi besi berdasarkan jenis kelamin, riwayat kelahiran prematur atau BBLR, riwayat pemberian ASI Eksklusif dan status gizi pada anak usia 12- 36 bulan di Wilayah Kerja Puskesmas Jatilawang Kabupaten Banyumas. Penelitian crosssectional, dengan jumlah sampel sebanyak 153 balita. Pengumpulan data dilakukan dengan kuesioner dan pengukuran berat badan untuk menilai status gizi balita serta pemeriksaan sampel darah untuk mengetahui kadar $\mathrm{Hb}$ dan feritin serum. Hasil penelitian menunjukkan prevalensi kejadian ADB di wilayah Puskesmas Jatilawang sebesar $18,4 \%$. Balita dengan jenis kelamin laki- laki memiliki hubungan yang signifikan terhadap kejadian ADB (OR: 230,53) dan dengan riwayat kelahiran premature/ BBLR memiliki hubungan yang signifikan besar kedua (OR : 141,32). Sedangkan riwayat pemberian ASI Eksklusif dan balita dengan status gizi kurang memiliki risiko sebesar 61 kali dan 10,4 kali mengalami ADB. Program skrinning anemia defisiensi besi pada anak balita perlu dilakukan oleh pemerintah sebagai salah satu upaya penanggulangan dini kejadian anemia.
\end{abstract}

Kata Kunci : Anemia Defisiensi Besi, Jenis Kelamin, Bayi Prematur

\section{Pendahuluan}

Anemia defisiensi besi merupakan penyakit nutrisi yang banyak terjadi di seluruh dunia. Menurut data dari WHO (World Health Organization), kejadian anemia defisiensi besi (ADB) yang terjadi di negara- negara industri dan negara- negara non- industri berturutturut sekitar 10- 20\% dan 50-60\%. ${ }^{1}$ Prevalensi anemia pada anak pra sekolah (0- 5 tahun) di seluruh dunia mencapai $47,7 \%$ dari seluruh total populasi yang menderita anemia. Prevalensi tertinggi ada di Asia Tenggara sebesar 65,5\%, dan di Indonesia mencapai 44,5\%. Oleh sebab itu Indonesia termasuk dalam wilayah rawan kasus anemia pada anak usia pra sekolah. 2

Sebagian besar kejadian anemia diseluruh dunia merupakan ADB dan hal ini berpengaruh kepada perempuanpada masa reproduksi dan anak- anak usia kurang dari 5 tahun. Anemia defisiensi besi dapat menyebabkan masalah kesehatan yang serius, seperti penurunan kecerdasan dan perkembangan motorik serta perilaku pada anak- anak.3Menurut The United States Centers for Desease Control and Prevention (US CDC), menjelaskan anak- anak yang memiliki risiko mengalami anemia defisiensi besi antara lain prematur atau bayi dengan berat badan lahir rendah, bayi yang diberikan susu sapi sebelum usia 12 bulan.4 Di kalangan anak-anak, anemia defisiensi besiadalahkonsekuensi dariinteraksi yang kompleksdaribeberapa faktor.

Pada beberapa hasil penelitian menyatakan bahwa anemia defisiensi besi berkaitan erat dengan prematur atau bayi berat badan lahir rendah, jenis kelamin, dan durasi menyusui. 5 Demikian pula dari hasil penelitian 
Olney, et. al (2007) menyebutkan bahwa anak yang mengalami kekurangan gizi dan anemia defisiensi besi akan mengalami hambatan dalam pertumbuhan motorik. ${ }^{6}$ Diagnosis anemia defisiensi besi ditegakkan berdasarkan hasil temuan dari anamnesis, pemeriksaan fisik dan laboratorium yang dapat mendukung sehubungan dengan gejala klinis yang sering tidak khas. ${ }^{7} \mathrm{Di}$ Indonesia program skrinning dan penanggulangan terhadap kejadian anemia defisiensi besi masih belum menjangkau pada kelompok anak balita. Sampai dengan saat ini program tersebut hanya difokuskan kepada kelompok ibu hamil. ${ }^{8}$ Penelitian ini bertujuan untuk mengetahui faktor risiko yang berkaitan dengan kejadian anemia defisiensi besi berdasarkan jenis kelamin, riwayat kelahiran premature atau berat badan lahir rendah, riwayat pemberian ASI Eksklusif dan status gizi pada anak usia 12- 36 bulan di Wilayah Kerja Puskesmas Jatilawang Kabupaten Banyumas.

\section{Metode Penelitian}

Penelitian ini merupakan penelitian crossectional untuk menentukan anemia defisiensi besi pada balita. Kriteria sampel dalam penelitian ini adalah balita sehat usia 12- 36 bulan dan orang tuanya yang tinggal di Wilayah Kerja Puskesmas Jatilawang Kabupaten Banyumas. Variabel bebas dalam penelitian ini adalah jenis kelamin, riwayat kelahiran prematur atau berat badan lahir rendah, riwayat pemberian susu formula dan status gizi, sedangkan variabel terikatnya adalah anemia defisiensi besi pada balita usia 12- 36 bulan.

Penelitan dilakukan dengan menggali data sekunder melalui lembar kuesioner kepada orang tua bayi dan melakukan penilaian terhadap status gizi anak balita dengan menghitung berat badan berdasarkan usia sesuai kurva WHO. Pemeriksaan sampel darah balita dilakukan untuk mengetahui kadar hemoglobin dengan metode cyanmethemoglobin dan prosedur pemeriksaan kadar feritin serum dilakukan menggunakan metode ELISA melalui alat MiniVidas- Biomerieux's. Batasan anemia bila kadar $\mathrm{Hb}<11 \mathrm{gr} / \mathrm{dl}$, sedangkan anemia defisiensi besi bila kadar $\mathrm{Hb}<11 \mathrm{~g} / \mathrm{dl}$ dan kadar feritin serum < $12 \mu \mathrm{g} / \mathrm{L}$. Analisis yang dilakukan dengan metode chi- square.

\section{Hasil dan Pembahasan}

Penelitian dilaksanakan pada 152 anak balita usia $<24$ bulan yang datang ke posyandu pada 5 desa yang ada di Wilayah Kerja Puskesmas Jatilawang.

Tabel 1. Karakteristik Responden

\begin{tabular}{lll}
\hline Karakteristik Responden & $\mathrm{n}$ & $\%$ \\
\hline Jenis Kelamin & & \\
Laki- laki & 40 & 26,3 \\
Perempuan & 112 & 73,7 \\
$\begin{array}{l}\text { Post BBLR/ Prematur } \\
\text { Ya }\end{array}$ & 16 & 10,5 \\
Tidak & 136 & 89,5 \\
ASI Eksklusif & & \\
Ya & 136 & 89,5 \\
Tidak & 16 & 10,5 \\
$\begin{array}{l}\text { Status Gizi } \\
\text { Kurang }\end{array}$ & & \\
Baik & 30 & 19,7 \\
Anemia Defisiensi Besi & 122 & 80,3 \\
Anemia & & \\
Tidak Anemia Defisiensi & 28 & 124 \\
Besi & 81,6 \\
\hline
\end{tabular}

Mengacu kepada database mikronutrien dari $\mathrm{WHO}$, prevalensi anemia defisiensi besi yang terjadi di dunia pada anak pra sekolah usia 6- 59 bulan pada tahun 2011 sekitar 43\% sedangkan prevalensi di wilayah Asia Tenggara sebesar 53,8\%. Data kejadian di Indonesia pada tahun 2011 sebesar $32 \%$. Di wilayah kerja Puskesmas Jatilawang, prevalensi kejadian anemia defieisnsi besi sebesar 18,4\% dan angka ini tidak dapat dibandingkan dengan wilayah lain karena data mengenai kejadian anemia pada anak balita belum ada. Menurut WHO, anak usia 6- 59 bulan merupakan salah satu kelompok dengan risiko tinggi kejadian anemia defisiensi besi selain remaja, ibu hamil dan menyusui. ${ }^{9}$ Menurut hasil penelitian anak balita dengan jenis kelamin perempuan lebih banyak mengalami 
anemia. Sebagian bayi yang memiliki riwayat kelahiran prematur/berat badan lahir rendah dan tidak diberikan ASI
Eksklusif serta hanya diberikan susu formula mengalami anemia defisiensi besi.

Tabel 2. Hubunganfaktor risiko kejadian anemia defisiensi besi pada anak usia 12- 36 bulan di Wilayah Puskesmas Jatilawang Kabupaten Banyumas

\begin{tabular}{|c|c|c|c|c|c|c|c|c|}
\hline \multirow{3}{*}{ Variabel } & \multicolumn{5}{|c|}{ Kejadian Anemia Defisiensi Besi } & \multirow{3}{*}{$P$ value } & \multirow{3}{*}{ OR } & \multirow{3}{*}{ CI $95 \%$} \\
\hline & \multicolumn{2}{|c|}{$\begin{array}{c}\text { Anemia } \\
\text { Defisiensi } \\
\text { Besi }\end{array}$} & \multicolumn{2}{|c|}{$\begin{array}{c}\text { Tidak Anemia } \\
\text { Defisiensi } \\
\text { Besi }\end{array}$} & \multirow[t]{2}{*}{ Total } & & & \\
\hline & $N$ & $\%$ & $n$ & $\%$ & & & & \\
\hline \multicolumn{9}{|l|}{ Jenis Kelamin } \\
\hline Laki- laki & 27 & 67,5 & 13 & 32,5 & 40 & 0,00 & 230,53 & $28,88-1839,77$ \\
\hline Perempuan & 1 & 0,9 & 111 & 99,1 & 112 & & & \\
\hline \multicolumn{9}{|l|}{ Riwayat Kelahiran } \\
\hline Post BBLR/ Prematur & 15 & 93,8 & 1 & 6,3 & 16 & 0,00 & 141,32 & $17,32-1162,91$ \\
\hline $\begin{array}{l}\text { Non- post BBLR/ } \\
\text { Prematur }\end{array}$ & 13 & 9,6 & 123 & 90,4 & 136 & & & \\
\hline \multicolumn{9}{|c|}{ Pemberian ASI Eksklusif } \\
\hline Tidak & 14 & 87,5 & 2 & 12,5 & 16 & 0,00 & 61,0 & $12,54-296,58$ \\
\hline Ya & 14 & 10,3 & 122 & 89,7 & 136 & & & \\
\hline \multicolumn{9}{|l|}{ Status Gizi } \\
\hline Kurang & 16 & 53,3 & 14 & 46,7 & 30 & 0,00 & 10,47 & $4,123-26,618$ \\
\hline Baik & 12 & 9,8 & 110 & 90,2 & 122 & & & \\
\hline
\end{tabular}

Berdasarkan tabel 2. Menunjukkan bahwa hubungan antara jenis kelamin dengan kejadian anemia defisiensi besi memiliki hasil signifikan. (OR: 230,53, p value : 0,00$)$. Hal ini sesuai dengan hasil penelitian Woldie, et. al (2015) menyatakan bahwa anak laki- laki berisiko 3 kali lebih besar untuk mengalami anemia dibanding dengan anak perempuan $(\mathrm{AOR}=3,1,95 \% \mathrm{CI}$ : 1,60- 5,81). ${ }^{5}$ Keadaan ini dijelaskan oleh Helmiyati, dkk (2007) bahwa pertambahan berat badan bayi laki- laki lebih cepat dibandingkan dengan bayi perempuan, akibatnya zat besi yang dipergunakan dalam proses tumbuh kembang akan lebih cepat terpakai. ${ }^{11}$

Pada variabel riwayat berat badan lahir rendah/ prematur diperoleh hasil mengenai hubungan anemia defisiensi besi dan riwayat kelahiran prematur/ BBLR yang memiliki taraf signifikansi besar (OR : 141,32) Penelitian yang dilakukan oleh Gizela, et. al. (2014) menyatakan bahwa anak yang lahir dengan berat badan lahir rendah memiliki risikomengalami anemia defisiensi besi 1,74 kali dibandingkan dengan anak dengan riwayat kelahiran normal $(95 \%$ CI: 1,04- 2,92). Anak- anak yang lahir dengan berat badan lahir rendah/ prematur memiliki beban ganda dalam kehidupannya, hal ini disebabkan karena selama 2 tahun masa pertumbuhannya mereka mengalami fase tercepat dan dalam tahap ini akan membutuhkan cadangan zat besi dalam sel darah merah proses pertumbuhannya. 9,10

Dalam penelitian ini, anak usia 1236 bulan yang tidak mendapatkan ASI eksklusif berisiko $61 \mathrm{kali}(95 \% \mathrm{CI}=$ 12,54- 296,58) mengalami anemia defisiensi besi dibandingkan dengan anak yang mendapatkan ASI eksklusif dan diperoleh adanya hubungan yang bermakna antara riwayat pemberian ASI eksklusif dengan kejadian anemia defisiensi besi $(\mathrm{p}=0,00)$.

Hasil penelitian ini sejalan dengan pernyataan Meinzen (2006) bahwa bayi yang tidak mendapatkan ASI eksklusif selama 4 - 6 bulan memiliki risiko 18,4 kali lebih tinggi mengalami anemia defisiensi besi dibandingkan bayi yang mendapatkan ASI eksklusif (OR 18,4, 95\% CI 1,9- 174,0). 12

ASI eksklusif dianjurkan untuk diberikan kepada bayi sampai dengan usia 6 bulan dan dengan memberikan makanan pendamping pada awal usia 6 bulan, setelah itu dilanjutkan dengan tetap memberikan ASI sampai usia 2 tahun. Kandungan zat besi pada ASI turun kira- kira $1 \mathrm{mg} / \mathrm{L}$ sampai kurang dari $0,5 \mathrm{mg} / \mathrm{L}$ selama 6 bulan pertama menyusui, dan makin menurun jika masih terus menyusui. Meskipun zat besi dalam ASI sangat bioavailable 
(penyerapan 50\%), kandungan besi yang terdapat pada ASI berada pada titik tertinggi dalam susu transisi awal dan menurun terus selama laktasi. Secara umum, bayi yang lahir cukup bulan dan dengan berat badan lahir normal memiliki cadangan besi yang cukup sampai dengan usia 4- 6 bulan pertama kehidupan. American Academy of Pediatrics (AAP) sebelumnya telah menyarankan untuk pemberian suplementasi zat besi $(1 \mathrm{mg} / \mathrm{kg} / \mathrm{hari})$ mulai usia 4 bulan keatas kepada semua bayi yang diberikan ASI eksklusif maupun tidak. Hal ini dilakukan sebagai salah satu upaya untuk mencegah terjadinya anemia defisiensi besi pada bayi setelah usia 6 bulan sebelum bayi benar- benar mendapatkan asupan makanan pengganti ASI yang cukup mengandung zat besi. ${ }^{7}$

Anak usia 12- 36 bulan yang mempunyai status gizi kurang berisiko untuk mengalami anemia defisiensi besi sebesar 10,47 kali dibandingkan anak yang mempunyai status gizi baik ( $95 \%$ CI: 4,123- 26,618). Temuan penelitian ini didukung dengan penelitian yang dilakukan oleh Gebreegziabiher, et. al. (2014) diperoleh hasil bahwa anak- anak usia 6-59 bulan yang mengalami gizi kurang berisiko mengalami anemia defisiensi besi 2,0 kali dibanding dengan anak yang mempunyai gizi baik (OR = 2,05, 95\% CI $=1,3-3,3$ ), dan terbukti signifikan secara statistik ( $\mathrm{p}$ value $=$ 0,05). 13

Menurut Nugrohowati (2014), status gizi merupakan gambaran dari kecukupan asupan gizi makro, akan tetapi kecukupan gizi makro tidak dapat menjamin terpenuhinya kecukupan gizi mikro ketika makanan yang dikonsumsi rendah nutrisi. Sehingga sering dijumpai seseorang dengan status gizi baik tetapi status zat besinya kurang. Oleh karena itu, defisiensi gizi mikro sering disebut sebagai "kelaparan yang tersembunyi". Kementrian kesehatan pada tahun 2012 telah mencanangkan Gerakan "Scaling Up Nutrition (SUN Movement)" yang bertujuan untuk menurunkan masalah gizi, dengan fokus pada 1000 hari kehidupan pertama kehidupan (270 hari selama kehamilan dan 730 hari dari kelahiran sampai usia 2 tahun) yaitu pada ibu hamil, ibu menyusui dan anak usia 123 bulan. Gerakan 1000 Hari Pertama Kehidupan (HPK) terdiri dari dari intervensi gizi spesifik dan intervensi gizi sensitif. Intervensi gizi spesifik yang dilakukan antara lain seperti imunisasi, PMT ibu hamil dan balita, monitoring pertumbuhan balita di Posyandu, suplemen tablet besi- folat ibu hamil, promosi ASI eksklusif, MP- ASI dan sebagainya. Gerakan ini telah dilaksanakan oleh Puskesmas Jatilawang dalam menangani bayi dengan status gizi kurang seperti dukungan pemberian ASI eksklusif, pemberian suplementasi makanan (Taburia) kepada bayi melalui kelompok posyandu, melakukan pelayanan kesehatan pada anak balita (penimbangan berat badan balita secara rutin di posyandu), serta memberikan penanganan dan perawatan pada kasus gizi buruk di wilayah kerja Puskesmas Jatilawang. Akan tetapi sampai dengan saat ini, penanganan bayi dengan underweight masih terbatas pada pemberian suplemen makanan dan tidak diikuti dengan skrining atau penapisan terhadap risiko jangka panjang seperti skrining anemia defisiensi besi. Hal ini disebabkan karena pemeriksaan penunjang terhadap kondisi anemia defisiensi besi pada bayi dan balita belum dilaksanakan sebagai program pelayanan kesehatan bayi dan balita di tingkat puskesmas. Pemerintah hanya melaksanakan program skrining dan penanggulangan anemia pada ibu hamil saja. Pada masa yang akan datang hal ini dapat menjadi usulan program pemerintah dalam upaya penanggulangan masalah gizi pada balita yang berkaitan dengan anemia defisiensi besi.

\section{Kesimpulan}

Hasil penelitian menunjukkan prevalensi kejadian anemia defisiensi besi pada anak usia 12- 36 bulan di Wilayah Puskesmas Jatilawang Kabupaten Banyumas sebesar 18,4\%. Anak dengan jenis kelamin laki- laki memiliki hubungan yang erat terhadap kejadian anemia defisiensi besi. Faktorfaktor lain yang berkaitan dengan 
kejadian anemia defisiensi besi antara lain adalah riwayat kelahiran premature atau berat badan lahir rendah, riwayat pemberian ASI Eksklusif dan Status Gizi. Pemerintah memiliki tugas untuk mengkaji dan merencanakan program skrinning anemia defisiensi besi pada anak balita, sebagai salah satu upaya penanggulangan anemia sejak dini.

\section{Daftar Pustaka}

[1] Fatih Akin, Ece Selma Solak, Cengizhan Kilicaslan, Saltuk Bugra Boke (Departemen of Pediatrics, Konya Training and Reseacrh Hospital Meram, 42090 Konya T, Nefprhotic SASA (Departemen of PNHM 42090 KT. Iron Deficiency Anemia among Hospitalized Children in Konya, Turkey. Anemia. 2013;2013(http://dx.doi.org/10.1155/ 2013/514801):1-4.

[2] WHO. Worldwide Prevalence of Anemia 1993- 2005: WHO global database on anaemia. Benoist B de, Erin McLean IE and MC, editors. Geneva, Switzerland: WHO Press; 2008.

[3] Al-Qaouds, Nawal Mubarak (Administration of Food and Nutrition, Ministry of Health), AlShami, Entesar, Prakash P. Anemia and Associated Factors Among Kuwaiti Preschool Children and Their Mothers. Alexandria J Med. 2015;51:161-6.

[4] Bazian. Screening For Iron Deficiency Anemia in Children Under 5 Years of Age. United Kingdom; 2012. Report No.: version 2.

[5] Woldie, haile; Kebede, Yigsaw; Tariku A. Factors Associatedwith Anemia Among Children Aged 6- 23 Months Attending Growth Monitoring at Tsitsika Health Center, Wag- Himra Zone, Northeast Ethiopia. J Nutr. 2015;1-9.

[6] Olney, Deanna K., Pollit Ernesto, Kariger Patricia K., K.S.S., 2007. Young Zanzibari Children With Iron Deficiency, Iron Deficiency Anemia, Stunting, or Malaria Have Lower Motor Activity Scores and Spend
Less Time in Locomotion. J. Nutr., 137, pp.2756-2762.

[7] Raspati, Harry; Reniarti, Lelani; Susanah S. Buku Ajar HematologiOnkologi Anak. Ed. 3. Permono, Bambang; Staryo; Ugrasena, IDG; Windiastuti, Endang; Abdulsalam M, editor. Jakarta: Badan Penerbit IDAI; 2010. 30-43 p.

[8] Dewi, Sawitri (Midwifery Department, Health Science faculty $\mathrm{U}$ of MP, Suryantoro PS, (Postgraduate Program of Midwifery, Health Science Faculty 'Aisyiyah University Yogyakarta). International Conference on Applied Science and Health (ICASH) 2017. Improving Health and Well-being for Better Society. Indonesian Scholar's Alliance; 2017. p. 239-45.

[9] WHO. Iron Deficiency Anaemia Assessment, Prevention, and Control A guide for programme managers. NHD 01.3; 2001.

[10] Gisela M. Pita MD MS, Santa Jiménez MD PhD, Beatriz Basabe MS PhD, René G. García MD CMP, Lisette Selva MD, Clarisa Hernández MD, Margarita Cruz, Roxana Herrera MD MS, Regla O'Farrill MD IC, Karelia Paulí MD, Moraima Leyva, Caridad Arocha DH. Anemia in Children Under Five Years Old in Easttern Cuba. MEDICC Rev. 2014;16(1):16-23.

[11] Hidajat, Boerhan; Lestari ED. Buku Ajar Nutrisi Pediatrik dan Penyakit Metabolik. 1st ed. Syarif, Damayanti Rusli; Lestari, Endang Dewi; Mexitalia, Maria; Nasar SS, editor. Jakarta: Badan Penerbit IDAI; 2011. 190-207 p.

[12] Helmyati, Siti; Hadi, Hamam; Lestariana W. Kejadian Anemia Pada Bayi Usia 6 Bulan Yang Berhubungan Dengan Sosial Ekonomi Keluarga dan Usia Pemberian Makanan Pendamping ASI. Ber Kedokt Masy. 2007;23(No. 1):35-41.

[13] Meinzen- Derr, Jareen K.;Guerrero, Lourdes; Altaye, Mekibib; OrtegaGalegos, Hilda; Ruiz- Palacios, Guilermo M.; Morrow AL. Risk of Infant Anemia is ASSciated with 
Exclusive Breast- Feeding and Maternal Anemia in a Mexican Cohort. JN Nutr. 2005;452-8.

[14] Gebreegziabiher, Gebremedhin;

Etana, Belachev and Niguste D.
Determinants of Anemia among Children Aged 6-59 Months Living in Kilte Awulaelo Woreda, Northern Ethiopia. J Nutr. 2014;2014:1-9. 